\title{
Die begrip en produksie van persoonlike voornaamwoorde deur Afrikaanssprekende 6-jariges*
}

Frenette Southwood

Departement Algemene Taalwetenskap, Universiteit Stellenbosch, 7600 Stellenbosch, Suid-Afrika

E-pos: fs@sun.ac.za

\section{Inleiding}

Voornaamwoorde is besonder moeilik vir jong kinders om te bemeester, aangesien die vorm daarvan aanhoudend verander na gelang van die konteks: voornaamwoorde verander volgens die getal en geslag van die mense na wie verwys word, volgens wie die spreker en die hoorder is, en volgens die grammatikale rol van die voornaamwoord in die sin (Moore 2001: 208; Ricard, Girouard, en Gouin Décarie 1999: 68-69; kyk ook Campbell, Brooks, en Tomasello 2000). Voornaamwoorde se deiktiese eienskappe veroorsaak verder dat hulle nie aan kinders gemodeleer kan word sonder om moontlike verwarring te veroorsaak nie; kinders moet luister na die gebruik van voornaamwoorde in die taal van ander sprekers om vertroud te raak met die korrekte gebruik daarvan (Cole, Oshima-Takane, en Yaremko 1994: 115).

Die verwerwing van voornaamwoorde in Engels word reeds lank uitgebreid ondersoek (kyk bv. Cooley 1908 en Bain 1936), maar daar is nog nie 'n volledig uitgewerkte teorie wat al die feite kan verklaar nie, veral nie die gebruik van voornaamwoordkasus nie (Schütze 1999: 754). Daarenteen is data oor die ontwikkeling van die voornaamwoordsisteem in kindersprekers van ander tale nog skraps. Daar word egter aanvaar dat, ongeag die taal, elke voornaamwoord woord vir woord geleer moet word, aangesien daar geen algemene reëls is 
wat as gids kan dien tydens die aanleer van die fonetiese vorm van die voornaamwoord nie (Rispoli 1994, 1998a, 1998b).

Gestandaardiseerde taaltoetse wat gebruik word om taalprobleme by kinders te diagnoseer sluit gereeld items in wat die begrip en produksie van voornaamwoorde evalueer. Daar is drie gestandaardiseerde taaltoetse vir gebruik met Afrikaanssprekende kinders, nl. die Toets vir Mondelinge Taalproduksie (Vorster 1980), die Afrikaanse Semantiese Taalevalueringsmedium (Pretorius 1989), en die Afrikaanse Reseptiewe Woordeskattoets (Buitendag 1994). Van hierdie drie bevat slegs die Afrikaanse Semantiese Taalevalueringsmedium 'n subtoets vir die evaluering van begrip en produksie van voornaamwoorde.

Waar hierdie beperkte subtoets nie uitgevoer word nie, maak evalueerders (soos spraaktaalterapeute en onderwysers) gebruik van self-opgestelde informele toetse om vas te stel hoe kinders voornaamwoorde verstaan en gebruik. Om die resultate van hierdie informele toetse te kan interpreteer (d.i., om te kan besluit of 'n kind se ontwikkeling van kennis oor voornaamwoorde tipies, afwykend, of vertraag is) word normatiewe data benodig. Onlangse gegewens wat op 'n wydverspreide populasie genormeer is, is nie vir Afrikaans beskikbaar nie. Die algemene gebruik is om enige verskil tussen die kennis van voornaamwoorde van volwasse sprekers van Afrikaans en dié van kindersprekers van 6 jaar en ouer as atipies te beskou en remediërend op te tree. Die vraag ontstaan egter of Afrikaanssprekende kinders se ontwikkeling ten opsigte van persoonlike voornaamwoorde reeds teen 6 jaar afgehandel is en, indien nie, watter tipe foute as tipies en watter as afwykend beskou kan word. Die studie wat hier bespreek word, is uitgevoer in 'n poging om hierdie vraag te begin beantwoord.

\section{Metodologie}

\subsection{Deelnemers}

Twintig Afrikaanssprekende 6-jariges uit eentalige Afrikaanssprekende huise het aan die studie deelgeneem. Al die deelnemers het volgens hul ouers en klasonderwyseresse normale gehoor en tipiese intellektuele ontwikkeling getoon en het geen tekens van neurologiese afwykings of emosionele probleme gehad nie. Tien van die deelnemers se taalontwikkeling was volgens hul ouers en klasonderwyseresse tipies vir hul ouderdom terwyl die ander 10 
deur spraak-taalterapeute as taalgestremd gediagnoseer is. Inligting oor die middele waarmee hierdie diagnose deur die terapeute gemaak is, word in bylae A1 en A2 gegee. Kinders met taalgestremdheid is slegs in die studie ingesluit indien (i) hul reseptiewe taalouderdomstelling ten minste 6 maande onder die laagste een van hul mentale of kronologiese ouderdom was; (ii) hul ekspressiewe taalouderdomstelling ten minste 12 maande onder die laagste een van hul mentale of kronologiese ouderdom was; of (iii) hul gekombineerde ouderdomstelling ten minste 12 maande onder die laagste een van hul mentale of kronologiese ouderdom was (kyk bv. Stark en Tallal 1981).

Al die tipies-ontwikkelende deelnemers het in Stellenbosch gewoon en/of skoolgegaan. Uit die 10 deelnemers met taalgestremdheid was drie in Bloemfontein woonagtig, twee in die noordelike voorstede van Kaapstad, twee in Oudtshoorn, een in Somerset-Wes, en een in Hartenbos. Al twintig deelnemers was volgens hul onderwyseresse en/of terapeute sprekers van sogenaamde Standaardafrikaans.

\section{2 $\quad$ Prosedures}

Die tipies-ontwikkelende kinders is via hul dag- of nasorgsentra gekontak terwyl die kinders met taalgestremdheid deur hul spraak-taalterapeute na die studie verwys is. Nadat toestemming vir deelname aan die studie van die deelnemers en hul ouers verkry is, het al 20 deelnemers 'n gehoorsiftingstoets ondergaan (volgens die riglyne van die American Speech, Language, and Hearing Association (ASHA) 1997-2006), om te verseker dat hul gehoor binne normale perke is. Slegs kinders met taalgestremdheid wat 'n nie-verbale IK-telling van 85 of hoër gehad het, het as deelnemers gekwalifiseer (kyk Stark en Tallal 1981). Waar IKtellings nie reeds beskikbaar was nie, is potensiële deelnemers na opvoedkundige sielkundiges verwys vir toetsing. Hierna is drie eksperimentele take wat deur die navorser opgestel is met elke deelnemer indiwidueel uitgevoer. Elke taak het oefenitems gehad om die deelnemers vertroud te maak met die taak. Die take is vooraf, tydens 'n loodsstudie, toegepas om vas te stel of die leksikale items aan voorskoolse kinders bekend is en of die kognitiewe eise wat aan die kinders gestel word, redelik is (kyk Southwood 2005, 2006). 'n Spontane taalmonster van 30 minute is ook versamel tydens vryespel met houtblokkies, plastiek kombuismeubels, en mannetjies met bybehore soos hoedjies, bekers, en besems. Tydens taalmonsterontlokking het die navorser en deelnemer alleen in 'n stil kamer in sy/haar skool, dagsorgsentrum, of huis gespeel. Die navorser het die sessie begin deur die deelnemer uit te nooi om saam met haar 
die mannetjies aan te trek, 'n huis met die blokkies te bou, en/of die kombuismeubels reg te rangskik. As 'n deelnemer vir lang periodes stil was, het die navorser verskeie tegnieke gebruik om gesprek aan te moedig, insluitend die maak van stellings (aan haarself of aan die deelnemer gerig) en die vra van beide $w$ - en ja/nee-vrae. Hierdie vrae het oor onderwerpe gehandel soos verjaarsdagvieringe, troeteldiere, en deelnemers se families - onderwerpe wat deur Southwood en Russell (2004) geskik gevind is vir bespreking met voorskoolse kinders.

\subsection{Eksperimentele take}

Twee begrips- en een produksietaak is uitgevoer. In die literatuur is daar geen voorbeelde van eksperimentele take wat gebruik kan word om voornaamwoordbegrip en -gebruik by voorskoolse kinders te toets nie. In hierdie studie is daar dus van self-opgestelde take gebruik gemaak. Hierdie take is egter gebaseer op take wat met sukses gebruik is om die begrip en/of gebruik van meervoudsvorme, kasus, en tydsvorme deur voorskoolse kinders van verskeie taalagtergronde te toets (kyk bv. Håkansson 2001; Hansson en Leonard 2003; Leonard, Salameh, en Hansson 2001; Loeb en Leonard 1991; Marchman, Saccuman, en Wulfeck 2004; Ravid, Levie, en Ben-Zvi 2003).

Alle toetsitems verskyn in bylaag B. In Afrikaans word voornaamwoorde vir kasus, persoon, en getal gemerk. By die tweedepersoon word daar verder 'n onderskeid getref tussen formele en informele aanspreekvorme en by die derdepersoon in die enkelvoud tussen semantiese geslag. Alle persoon-getal-kasus-semantiese geslag-kombinasies is getoets, maar die formele vorm van die tweedepersoon is nie getoets nie.

Die eerste begripstaak het prentseleksie behels. Die deelnemer is 'n prent van 'n vrou gewys en ingelig dat hierdie vrou deurgaans die navorser sal wees. Hierna is die manlike deelnemers 'n prent van 'n seun en die vroulike deelnemers 'n prent van 'n meisie gewys en ingelig dat dit hulle is. Oefenitems is gebruik om te verseker dat die deelnemers hierdie verduidelikings verstaan het. Hierna is die deelnemer 'n vel papier met vier prente gewys en gevra om te wys na dié prent wat by die navorser se uiting pas. Daar is byvoorbeeld aan die deelnemer 'n vel met die volgende prente van 'n persoon of persone wat by 'n tafel sit, gewys: een van 'n vrou (nie die navorser nie) en die kind wat die deelnemer verteenwoordig; een van twee vrouens; een van 'n vrou en 'n kind (wat die navorser en deelnemer verteenwoordig); en een van die 
kind wat die deelnemer verteenwoordig op sy/haar eie. Die navorser sê dan Wys vir my "Julle sit by die tafel". Die deelnemer het dus 'n keuse tussen 'n prent wat pas by Julle sit by die tafel (die teiken), Hulle sit by die tafel of Ons sit by die tafel (waar die getal van die voornaamwoord dieselfde gehou word maar die persoon van dié van die teiken verskil), en Jy sit by die tafel (waar die persoon van die voornaamwoord dieselfde gehou word maar die getal van dié van die teiken verskil). Die taak het uit 32 items bestaan: elke persoon-getal-kasusgeslag-kombinasie is een maal getoets.

Die tweede begripstaak was 'n oordeeltaak. Die doel hiervan was om vas te stel of die deelnemer korrekte en verkeerde gebruik van voornaamwoorde deur die navorser kon herken. Tydens hierdie taak het die navorser en deelnemers na prente gekyk van mense en diere wat verskeie aksies uitvoer (bv. van 'n seun wat deur 'n koei gejaag word) terwyl die navorser 'n beskrywing van die prent gee. Hierdie beskrywing was óf (i) grammatikaal en het by die prent gepas (Die koei jaag hom), óf (ii) ongrammatikaal maar het by die prent gepas (*Die koei jaag hy), óf (iii) het nie by die prent gepas nie (Die koei jaag hulle). Hierdie taak het ook uit 32 items bestaan, met elke persoon-getal-kasus-geslag-kombinasie wat een maal getoets is.

Die produksietaak het sinsvoltooiing behels. Twee prente is aan die deelnemer gewys terwyl die navorser 'n sin begin sê waarvan die eerste deel by die eerste prent pas. Daar is dan van die deelnemer verwag om die sin só te voltooi dat die tweede deel by die tweede prent pas. Die navorser het byvoorbeeld gewys na 'n prent van 'n seun wat 'n eekhoring voer en gesê: $H y$ voer die eekhorinkie, maar ... en dan gewys na 'n prent van 'n meisie wat voëls voer. Deelnemers is vooraf gesê dat "ons in hierdie speletjie nie gaan praat van die dogtertjie, die oom of die hond nie, maar van ons, hy, sy, julle, en so aan". Die taak het uit 64 items bestaan, met twee geleenthede om elke persoon-getal-kasus-geslag-kombinasie te produseer.

\subsection{Data-transkripsie en -optekening}

Die response op die items van die eksperimentele take is op self-opgestelde toetsvorms aangeteken. Spontane selfkorreksies is deurgaans toegelaat en voor-finale response is geïgnoreer. Response is as volg gekategoriseer: (i) korrekte response, (ii) verkeerde response, en (iii) onbruikbare response. Laasgenoemde sou insluit response waar 'n deelnemer na twee of meer prente gewys het tydens die prentseleksietaak, waar die deelnemer Ek weet nie in plaas van ja of nee gesê het tydens die oordeeltaak, of waar 'n voornaamwoord deur 'n 
naamwoord vervang is of waar bv. hulle deur hy en sy vervang is tydens die sinsvoltooiingstaak. Waar 'n deelnemer geen respons op 'n item van enige van die drie take gegee het nie, is dit ook as onbruikbaar gekategoriseer.

Die eerste 100 uitinge wat in die taalmonster van elke deelnemer voorgekom het, is ortografies getranskribeer, insluitende uitinge wat kort onverstaanbare segmente bevat. Uitinge wat 'n woordelikse herhaling van die voorafgaande uiting van die navorser was asook deelnemers se herhalings van hul eie direk-voorafgaande uitinge is nie ingesluit nie (kyk Johnston 2001: 158). Brown (1973: 54) se riglyne - dat vullers soos um en o geïgnoreer word terwyl ja en nee ingesluit word - is gevolg. Die aantal kere wat persoonlike en besitlike voornaamwoorde korrek en verkeerd gebruik is, is getel en opgeteken. Verkeerde gebruik is beskou as vervanging van 'n voornaamwoord met een wat verskil in terme van getal, persoon, semantiese geslag, kasus of 'n kombinasie van enige van dié vier aspekte. Geen ontoepaslike weglating van voornaamwoorde uit verpligte kontekste het voorgekom nie, so die verkeerde gebruik van voornaamwoorde sluit nie weglatings in nie. Natuurlike ellipsis het wel voorgekom (bv. in Gaan nou met hom speel in plaas van Ek gaan nou met hom speel), maar aangesien dit aanvaarbaar is in spontane gesprekvoering is dit nie as ' $\mathrm{n}$ fout aangeteken nie.

\subsection{Statistiese ontleding}

Daar is nie verwag dat die verspreiding van tellings in die twee groepe normaal sal wees nie, want monsters van kinders met spesifieke taalgestremdheid neig tot heterogeniteit. Hierdie heterogeniteit kan nie beperk word as die monstergrootte so klein is soos hierdie studie s'n nie. Om hierdie rede is die nie-parametriese Mann-Whitney-toets gebruik wat die gemiddelde rangordes toegeken aan die gevalle in die twee groepe bereken, en sodoende kontroleer vir buitengewoon goeie of swak prestasie van indiwiduele deelnemers. Die vlak van beduidendheid is deurgaans as 0.05 geneem.

\section{Resultate en bespreking}

In die drie onderstaande tabelle word die response van elke deelnemer op die drie take eers apart gegee en daarna word 'n gemiddeld vir elke groep (die groep deelnemers met spesifieke taalgestremdheid en die groep tipies-ontwikkelendes) gegee. Resultate word telkens 
aangebied in die vorm van persentasies. Slegs korrekte en verkeerde response (nie onbruikbares nie) is in ag geneem.

Die resultate van die prentseleksietaak word in Tabel 1 weergegee. Eers word daar aangedui watter persentasie van die prente korrek geselekteer is. Daarna word daar aangedui watter van die geselekteerde prente (korrek of nie) wel verteenwoordigend was van 'n voornaamwoord met onderskeidelik dieselfde getal, persoon, en semantiese geslag as die teiken.

Tabel 1. Persentasie korrekte response op die prentseleksietaak

\begin{tabular}{|c|c|c|c|c|c|c|c|c|}
\hline \multirow[t]{2}{*}{$\overline{\text { Oud }^{1}}$} & \multicolumn{2}{|c|}{ Vnw korrek } & \multicolumn{2}{|c|}{ Getal korrek } & \multicolumn{2}{|c|}{ Persoon korrek } & \multicolumn{2}{|c|}{ Geslag korrek $^{4}$} \\
\hline & $\mathrm{STG}^{2}$ & $\mathrm{TO}^{3}$ & $\overline{\text { STG }}$ & $\mathrm{TO}$ & STG & $\mathrm{TO}$ & STG & $\mathrm{TO}$ \\
\hline $6 ; 0$ & $44^{5}$ & - & 72 & - & 66 & - & 83 & - \\
\hline $6 ; 0$ & 66 & - & 78 & - & 69 & - & 100 & - \\
\hline $6 ; 1$ & - & 59 & - & 94 & - & 69 & - & 58 \\
\hline $6 ; 2$ & - & 81 & - & 97 & - & 81 & - & 100 \\
\hline $6 ; 3$ & - & 91 & - & 100 & - & 94 & - & 93 \\
\hline $6 ; 4$ & 100 & 94 & 100 & 100 & 100 & 94 & 100 & 100 \\
\hline $6 ; 6$ & - & 91 & - & 97 & - & 94 & - & 92 \\
\hline $6 ; 7$ & 59 & 91 & 78 & 97 & 78 & 94 & 67 & 93 \\
\hline $6 ; 7$ & $45^{5}$ & - & 94 & - & 65 & - & $64^{6}$ & - \\
\hline $6 ; 8$ & 84 & 94 & 91 & 100 & 91 & 97 & 92 & 93 \\
\hline $6 ; 9$ & 31 & 81 & 66 & 100 & 56 & 91 & 58 & 75 \\
\hline $6 ; 11$ & 56 & 78 & 88 & 91 & 69 & 84 & 83 & 92 \\
\hline $6 ; 11$ & 72 & 84 & 100 & 100 & 75 & 88 & 92 & 92 \\
\hline $6 ; 11$ & 91 & - & 100 & - & 91 & - & 100 & - \\
\hline \multirow[t]{3}{*}{$\mathrm{Gem}^{7}$} & 65 & 84 & 87 & 98 & 76 & 88 & 92 & 88 \\
\hline & (208/ & (270/ & (276/ & (312/ & (242/ & (283/ & (100/ & (106/ \\
\hline & 319) & 320) & 319) & 320) & 319) & 320) & 119) & 120) \\
\hline
\end{tabular}

Notas: (1) Ouderdom in jare;maande. (2) Deelnemers met spesifieke taalgestremdheid. (3) Tipies-ontwikkelende deelnemers. (4) Slegs derdepersoon-enkelvoud voornaamwoorde is hier in ag geneem. (5) Een respons uit die 32 was onbruikbaar. (6) Een respons uit die 12 was onbruikbaar. (7) Groepsgemiddeld.

Dit blyk dat die deelnemers met spesifieke taalgestremdheid swakker gevaar het in terme van hul begrip van voornaamwoorde as die tipies-ontwikkelendes. Kenmerke waarmee die meeste foute gemaak is, was persoon vir die groep met taalgestremdheid, maar persoon en geslag vir die tipies-ontwikkelendes. 'n Voorbeeld van 'n persoonsfout is waar die prent wat pas by Die 
reën val op ons geselekteer word in plaas van die teikenprent wat pas by die Die reën val op hulle, terwyl 'n voorbeeld van 'n fout rakend geslag is waar Hy eet roomys geselekteer word in plaas van Sy eet roomys.

Die statisties beduidende verskille tussen die twee groepe was vir totale aantal voornaamwoorde korrek $(\mathrm{p}=0.044)$, getalkenmerk korrek $(\mathrm{p}=0.045)$, en persoonkenmerk korrek $(\mathrm{p}=0.033)$. Vir die aantal kere waarop die semantiese geslag van die voornaamwoord korrek aangedui is, was daar egter nie 'n statisties beduidende verskil tussen die twee groepe nie $(\mathrm{p}=0.464)$.

Tabel 2 bevat die response op die oordeeltaak. Ook in hierdie taak het die deelnemers met spesifieke taalgestremdheid beduidend swakker gevaar as die tipies-ontwikkelendes $(p=0.002)$. Soos wat die geval vir die prentseleksietaak was, het aantal korrekte response nie liniêr toegeneem met 'n toename in ouderdom (in maande) nie.

Tabel 2. Persentasie korrekte response op die oordeeltaak

\begin{tabular}{ccc}
\hline Ouderdom (jaar; maande) & STG $^{\mathbf{1}}$ & TO $^{\mathbf{2}}$ \\
\hline $6 ; 0$ & 50 & - \\
$6 ; 0$ & 50 & - \\
$6 ; 1$ & - & 66 \\
$6 ; 2$ & - & 84 \\
$6 ; 3$ & - & 78 \\
$6 ; 4$ & 84 & 81 \\
$6 ; 6$ & - & 72 \\
$6 ; 7$ & 53 & 84 \\
$6 ; 7$ & 53 & - \\
$6 ; 8$ & 56 & 88 \\
$6 ; 9$ & 50 & 78 \\
$6 ; 11$ & 72 & 78 \\
$6 ; 11$ & 50 & 81 \\
$6 ; 11$ & 72 & - \\
Gemiddeld & $\mathbf{5 9}(189 / 320)$ & $\mathbf{7 9}(253 / 320)$ \\
\hline
\end{tabular}

Notas: (1) Deelnemers met spesifieke taalgestremdheid. (2) Tipies-ontwikkelende deelnemers.

Die response van die twee groepe deelnemers op die sinsvoltooiingstaak word in Tabel 3 aangetref. Die persentasie korrekte response word eers aangedui, gevolg deur die persentasies 
response (korrek al dan nie) waarvan onderskeidelik die getal, persoon, kasus, en semantiese geslag met dié van die teiken ooreengestem het.

Tabel 3. Persentasie korrekte response op die sinsvoltooiingstaak

\begin{tabular}{|c|c|c|c|c|c|c|c|c|c|c|}
\hline \multirow[t]{2}{*}{ Oud $^{1}$} & \multicolumn{2}{|c|}{ Vnw. Korrek } & \multicolumn{2}{|c|}{ Getal korrek } & \multicolumn{2}{|c|}{ Persoon korrek } & \multicolumn{2}{|c|}{ Kasus korrek } & \multicolumn{2}{|c|}{ Geslag korrek $^{4}$} \\
\hline & $\mathrm{STG}^{2}$ & $\mathrm{TO}^{3}$ & STG & $\mathrm{TO}$ & STG & TO & STG & TO & STG & $\mathrm{TO}$ \\
\hline $6 ; 0$ & $59^{5}$ & - & 92 & - & 74 & - & 93 & - & 83 & - \\
\hline $6 ; 0$ & $77^{7}$ & - & 88 & - & 87 & - & 100 & - & 93 & - \\
\hline $6 ; 1$ & - & $75^{7}$ & - & 89 & - & 95 & - & 98 & - & 72 \\
\hline $6 ; 2$ & - & $96^{7}$ & - & 98 & - & 98 & - & 100 & - & 100 \\
\hline $6 ; 3$ & - & $88^{7}$ & - & 98 & - & 93 & - & 96 & - & 100 \\
\hline $6 ; 4$ & $95^{6}$ & 95 & 100 & 95 & 100 & 100 & 96 & 100 & 94 & 100 \\
\hline $6 ; 6$ & - & $52^{5}$ & - & 100 & - & 64 & - & 88 & - & 76 \\
\hline $6 ; 7$ & $66^{6}$ & $92^{6}$ & 90 & 98 & 78 & 95 & 95 & 100 & 95 & 94 \\
\hline $6 ; 7$ & $40^{6}$ & - & 89 & - & 60 & - & 91 & - & 50 & - \\
\hline $6 ; 8$ & $83^{6}$ & $93^{6}$ & 93 & 100 & 91 & 97 & 100 & 98 & 100 & 94 \\
\hline 6;9 & $41^{6}$ & $95^{6}$ & 75 & 100 & 72 & 96 & 91 & 98 & 57 & 94 \\
\hline $6 ; 11$ & $53^{5}$ & $93^{5}$ & 90 & 100 & 63 & 93 & 98 & 98 & 77 & 100 \\
\hline $6 ; 11$ & $80^{8}$ & $82^{6}$ & 100 & 93 & 89 & 91 & 91 & 96 & 100 & 100 \\
\hline $6 ; 11$ & $86^{8}$ & - & 96 & - & 96 & - & 94 & - & 100 & - \\
\hline \multirow[t]{3}{*}{$\mathrm{Gem}^{9}$} & 67 & 86 & 91 & 97 & 80 & 92 & 95 & 97 & 84 & 93 \\
\hline & (376/ & (474/ & (509/ & (538/5 & (448/ & (508/ & (530/ & (538/ & (163/ & (183/ \\
\hline & 560) & 553) & 560) & 53) & 560) & 553) & 560) & 553) & 193) & 196) \\
\hline
\end{tabular}

Notas: (1) Ouderdom in jare;maande. (2) Deelnemers met spesifieke taalgestremdheid. (3) Tipies-ontwikkelende deelnemers. (4) Slegs derdepersoon- enkelvoud voornaamwoorde is hier in ag geneem. (5) Een tot 4 response uit die 64 was onbruikbaar. (6) Vyf tot 8 response uit die 64 was onbruikbaar. (7) Nege tot 12 response uit die 64 was onbruikbaar. (8) Dertien tot 18 response uit die 64 was onbruikbaar. (9) Groepsgemiddeld.

Soos die geval vir die twee begripstake was, het die deelnemers met spesifieke taalgestremdheid ook in die produksietaak beduidend swakker gevaar as hul tipiesontwikkelende eweknieë ( $\mathrm{p}=0.028$ vir totale aantal voornaamwoorde korrek geproduseer; $\mathrm{p}=0.045$ vir getalkenmerk korrek gerealiseer). Alhoewel die tipies-ontwikkelendes beter gevaar het as die deelnemers met taalgestremdheid in terme van die korrekte realisering van kasus en semantiese geslag, was die verskille tussen groepe hier nie statisties beduidend nie ( $\mathrm{p}=0.123$ en $\mathrm{p}=0.308$ onderskeidelik). 
Die aspek wat deur beide groepe die meeste verkeerd gekry is, was persoon, maar selfs hier was daar 'n beduidende verskil tussen die twee groepe $(\mathrm{p}=0.037)$. Dit is opvallend dat deelnemers van beide groepe baie gereeld die gebruik van julle vermy het (deur bv. jy en sy te sê) of julle met hulle vervang het (lg. het ook gereeld in die prentseleksietaak voorgekom). Dit is onwaarskynlik dat hierdie gereelde vervanging van julle met hulle toegeskryf kan word aan 'n tekort aan perspektiefneming, aangesien Richard, Girouard, en Gouin Décarie (1999) bevind het dat kinders van 2 jaar 6 maande reeds daartoe instaat is om die perspektief van die spreker, hoorder, en nie-aangespreekte te verstaan. Meer waarskynlik is die Rispoliverduideliking dat hulle in plaas van julle herroep word omdat dié twee vorme fonologies nóú verwant is en moontlik ook omdat daar effens meer voornaamwoorde met die vorm $h$ - (hulle, haar, hy, hom) is as met die vorm $j$ - (jy, jou, julle).

Volgens Rispoli se Voornaamwoord Paradigma Bou Hipotese word die herroeping van 'n woord uit die voornaamwoordparadigma gelei deur die grammatikale kenmerke van die woord asook deur die fonologiese kenmerke van die voornaamwoordparadigma. As die korrekte voornaamwoord nie onmiddelik herroep kan word nie, word die kind se mentale "soektog" beïnvloed deur faktore soos die aantal selle wat die spesifieke woord in die paradigma vul, die fonologiese struktuur van die woord, en die fonetiese prominensie van die woord. Hierdie hipotese voorspel byvoorbeeld dat Engelssprekende kinders, as hulle nie onmiddelik she kan herroep nie, she met her sal vervang, onder andere omdat her meer male in die voornaamwoordparadigma voorkom as she ('n voorspelling wat deur die resultate van Rispoli (1998a) en Moore (1995) ondersteun is). Them mag ook onder sulke omstandighede deur they vervang word weens die groot ooreenkomste in fonologiese vorm van dié twee woorde. Anderson (1998) se bevindinge oor Spaanssprekende kinders bied ook ondersteuning vir Rispoli se hipotese: Meer kasusfoute is met die eerstepersoon nominatief yo begaan (waar die inhoud van die ander eerstepersoon-selle in die paradigma me of mio(a) is), as vir die tweedepersoon nominatief tú (waar die inhoud van die ander tweedepersoon-selle die fonologies-verwante te of tuyo(a) is).

Tabel 4 bevat die ontleding van die gebruik van persoonlike voornaamwoorde deur die twee groepe deelnemers in die spontane taalmonsters. Die ontleding word in die vorm van routellings gegee, d.i., die aantal kere wat elke voornaamwoord in die taalmonsters voorgekom het, word aangedui. Die totale aantal kere waarop voornaamwoorde gebruik is, 
was 537 vir die groep met taalgestremdheid (98.5\% daarvan korrek) en 859 vir die tipiesontwikkelende groep (100\% daarvan korrek). Die feit dat die deelnemers met taalgestremdheid opmerklik minder gebruik maak van voornaamwoorde as hul tipiesontwikkelende eweknieë dui moontlik op 'n poging tot vermyding van persoonlike voornaamwoorde deur kinders met taalgestremdheid.

Tabel 4. Aantal kere waarop voornaamwoorde gebruik is deur kinders met taalgestremdheid en tipies-ontwikkelendes in spontane taalmonsters

\begin{tabular}{|c|c|c|c|c|c|c|c|c|c|}
\hline \multirow[b]{2}{*}{$\underset{\mathscr{E}}{\mathscr{Z}}$} & \multicolumn{9}{|c|}{ Persoon } \\
\hline & $\begin{array}{c}1^{\mathrm{e}} \\
\text { ekv. }\end{array}$ & $\begin{array}{c}1^{\mathrm{e}} \\
\mathrm{mv} .\end{array}$ & $\begin{array}{c}2^{\mathrm{e}} \\
\text { ekv. }\end{array}$ & $\begin{array}{c}2^{\mathrm{e}} \\
\mathrm{mv}\end{array}$ & $\begin{array}{c}2^{\mathrm{e}} \text { ekv./mv. } \\
\text { formeel }\end{array}$ & $\begin{array}{l}3^{\mathrm{e}} \text { ekv. } \\
\text { manlik }\end{array}$ & $\begin{array}{l}3^{\mathrm{e}} \mathrm{ekv} . \\
\text { vroulik }\end{array}$ & $\begin{array}{c}3^{\mathrm{e}} \text { ekv. } \\
\text { ongeslagtig }\end{array}$ & $\begin{array}{c}3^{\mathrm{e}} \\
\mathrm{mv} .\end{array}$ \\
\hline Nom. & $e k$ & Ons & jy & julle & $u$ & hy & sy & dit & hulle \\
\hline $\mathrm{STG}^{1}$ & 164 & 19 & 28 & 2 & 0 & 68 & 12 & 59 & $28 / 33^{3}$ \\
\hline $\mathrm{TO}^{2}$ & 216 & 106 & 25 & 4 & 0 & 95 & 48 & 84 & 48 \\
\hline Gen. & my & ons & jou & julle & $u$ & sy & haar & sy & hulle \\
\hline STG & 44 & 3 & 7 & 1 & 0 & $17 / 19^{3}$ & 2 & 0 & 8 \\
\hline TO & 65 & 14 & 2 & 1 & 0 & 24 & 5 & 1 & 9 \\
\hline Dat. & $m y$ & ons & jou & julle & $u$ & hom & haar & dit/daar- & hulle \\
\hline STG & 3 & 2 & 2 & 0 & 0 & 9 & 3 & 4 & $5 / 6^{3}$ \\
\hline TO & 6 & 6 & 2 & 0 & 0 & 11 & 5 & 8 & 1 \\
\hline Akk. & $m y$ & ons & jou & julle & $u$ & hom & haar & $d i t$ & hulle \\
\hline STG & 1 & 2 & 1 & 0 & 0 & 23 & 0 & 6 & 6 \\
\hline TO & 4 & 0 & 1 & 0 & 0 & 17 & 1 & 47 & 3 \\
\hline
\end{tabular}

Notas: (1) Deelnemers met spesifieke taalgestremdheid. (2) Tipies-ontwikkelende deelnemers. (3) Aantal kere waarop 'n voornaamwoord korrek gebruik is uit die totale aantal kere waarop die voornaamwoord gebruik is.

Soos Tabel 4 aandui, is alle voornaamwoorde deurgaans korrek deur die tipiesontwikkelendes gebruik, terwyl die deelnemers met taalgestremdheid 'n klein aantal kere die verkeerde voornaamwoord in plaas van sy (manlik genitief) en hulle (nominatief en datief) gebruik het. Dit in teenstelling met beide groepe se tellings op die sinsvoltooiings- (ontlokte produksie-) taak, moontlik omdat kinders slegs daardie voornaamwoorde spontaan geproduseer het waarmee hulle gemaklik was, terwyl die sinsvoltooiingstaak van hulle verwag het om alle voornaamwoorde te produseer. 
Die resultate in Tabel 4 kontrasteer met dié van Moore (1995) wat bevind het dat Engelssprekende 5-jariges met spesifieke taalgestremdheid meer voornaamwoordfoute maak as tipies-ontwikkelende 5-jariges in 'n taalproduksietaak soortgelyk aan die een wat tydens taalmonsterontlokking in hierdie studie gebruik is. Moore (2001) het bevind dat Engelssprekende kinders (taalgestremd en tipies-ontwikkelend) geen produksiefoute met die persoon van voornaamwoorde gemaak het nie, en bykans geen met die getal nie. Foute met kasus en geslag is wel gemaak, maar tipies-ontwikkelende kinders het beduidend beter gevaar met korrekte produksie van kasus van voornaamwoorde as taalgestremdes. Hierteenoor het Moore (1995) se tipies-ontwikkelende kinders geen kasusfoute gemaak nie, terwyl hierdie tipe fout die algemeenste een van die kinders met taalgestremdheid was. Een rede wat Moore (1995: 69) aanvoer vir die hoë proporsie kasusfoute in die taal van kinders met spesifieke taalgestremdheid is dat kasus - anders as persoon, semantiese geslag of getal - nie korreleer met verskille in die regte wêreld nie. Kasus hang van die voornaamwoord se linguistiese konteks af, nie van die werklike geslag of getal van die referent(e) nie.

In hierdie studie is slegs 2 uit 'n moontlike 537 kasusfoute deur die kinders met taalgestremdheid begaan; beide kere was dit die genitiewe sy wat as hom gerealiseer is (soos in hom bene in plaas van sy bene). Daar is ook bevind dat kasus minder problematies is vir taalgestremde en tipies-ontwikkelende kinders as persoon en geslag. Dit blyk nie soseer uit die taalmonsters nie, maar wel uit die eksperimentele take. In hierdie opsig blyk die Afrikaanse data verkry in hierdie studie te verskil van die beskikbare Engelse data.

\section{Slot}

Dit blyk dat Afrikaanssprekende kinders - selfs dié sonder enige gerapporteerde taalprobleme - se ontwikkeling ten opsigte van persoonlike voornaamwoorde nog nie teen 6 jaar afgehandel is nie. Verder blyk dit dat Afrikaanssprekende kinders met en sonder taalgestremdheid dieselfde tipe fout maak in take van begrip en produksie van voornaamwoorde; die kinders met taalgestremdheid begaan net meer van hierdie foute as hul tipies-ontwikkelende eweknieë.

Rispoli (2005: 108) waarsku dat foute in voornaamwoordvorm - spesifiek in kasus - nie voorkom bloot omdat kinders se grammatika nog onvolwasse is nie. Selfs met 'n onvolwasse 
grammatika kan foute geminimaliseer word as kinders nie poog om meer ambisieus op te tree as waarvoor hulle die kapasiteit het nie. Hiermee word bedoel dat foute beperk kan word as kinders net dié selle van hul voornaamwoordparadigma gebruik waarvoor daar reeds inskrywings is en wat dus maklik herroepbaar is, en as naamwoorde en demonstratiewe in die plek van moeilik herroepbare voornaamwoorde gebruik word. Aangesien dit uit toetsing blyk dat Afrikaanssprekende 6-jariges se voornaamwoordgebruik nog nie dié van volwasse sprekers van die taal reflekteer nie (in die lig van die gebrek aan toepaslike norme vir volwassenes se voornaamwoordgebruik word daar aanvaar dat volwassenes geen sistematiese foute in ontlokte of spontane spraak sou maak nie), kan daar aanvaar word dat die hoë persentasie korrekte voornaamwoordgebruik in hul spontane taal ten minste deels toegeskryf kan word aan die strategie wat Rispoli beskryf.

Finestack, Fey, en Catts (2006) het Engelssprekende jong skoolgaande kinders met en sonder spesifieke taalgestremdheid se narratiewe ontleed in terme van hul gebruik van volledige voornaamwoordverwysings (m.a.w. hul gebruik van voornaamwoorde waar dit duidelik is waarna die voornaamwoord verwys). Daar is bevind dat volledige voornaamwoordverwysings as meting nie sensitief genoeg was om te onderskei tussen die twee groepe nie. 'n Soortgelyke bevinding is vir die Afrikaanssprekende kinders in hierdie studie gemaak: daar is geen noemenswaardige verskil tussen die kinders met en dié sonder taalgestremdheid in terme van hul akkuraatheid van voornaamwoordgebruik in spontane taal nie. Wanneer prentseleksie-, oordeel-, en sinsvoltooiingstake egter gebruik word (d.i., wanneer ontlokte in plaas van spontane voornaamwoordgebruik ondersoek word), blyk gebruik van persoonlike voornaamwoorde as meting wel sensitief genoeg te wees om tussen 6-jariges met en sonder spesifieke taalgestremdheid te onderskei. Weens die beperkte aantal deelnemers aan hierdie studie, kan so 'n veralgemening egter nog nie met 'n hoë mate van sekerheid gemaak word nie.

Benewens die beperkte aantal deelnemers, is daar 'n ander faktor wat die veralgemeenbaarheid van die bevindinge erg beperk, naamlik dat alle deelnemers aan hierdie studie sprekers van sogenaamde Standaardafrikaans was. Daar bestaan gedokumenteerde streeks- en dialektale verskille in die gebruik van voornaamwoorde; hierdie variasie is egter nie in dié studie in ag geneem nie. Om hierdie rede kan die resultate nie veralgemeen word na sprekers van nie-standaard variëteite van Afrikaans nie. 
Toekomstige studies oor hierdie onderwerp kan poog om meer deelnemers, deelnemers wie se Afrikaans as nie-standaard beskou word, deelnemers van 'n wye geografiese area, en/of deelnemers wat jonger as 6 is in te sluit. Dit behoort 'n bydrae te lewer tot die kennis oor voornaamwoord-ontwikkeling in die breë Afrikaanssprekende gemeenskap, wat tot meer akkurate diagnose van taalgestremdheid en meer doeltreffende remediëring van voornaamwoordbegrip en -gebruik mag lei.

* Hierdie materiaal is gebaseer op werk wat finansieel ondersteun is deur die Nasionale Navorsingstigting. Enige opinie, bevindings, gevolgtrekkings of aanbevelings in hierdie materiaal is dié van die outeur en gevolglik aanvaar die NNS geen verantwoordelikheid in hierdie verband nie.

\section{Verwysings}

American Speech and Hearing Association. 1997-2006. Hearing screening. http://www.asha. org/public/ hearing/testing/

Anderson, R.T. 1998. The development of grammatical case distinctions in the use of personal pronouns by Spanish-speaking preschoolers. Journal of Speech, Language, and Hearing Research 41: 394-406.

Bain, R. 1936. The self-and-other words of a child. The American Journal of Sociology 41: 767-775.

Brown, R. 1973. A first language: The early stages. Cambridge: Harvard University Press.

Buitendag, M.M. 1994. Afrikaanse Reseptiewe Woordeskattoets. Pretoria: Raad vir Geesteswetenskaplike Navorsing.

Campbell, A.L, P. Brooks, and M. Tomasello. 2000. Factors affecting young children's use of pronouns as referring expressions. Journal of Speech, Language, and Hearing Research 43: 1337-1349.

Cole, E.B., Y. Oshima-Takane, and R.L. Yaremko. 1994. Case studies of pronoun development in two hearing-impaired children: Normal, delayed or deviant? European Journal of Disorders of Communication 29: 113-129.

Cooley, C.H. 1908. A study of the early use of self-words by a child. Psychological Review 15: 339-357. 
Finestack, L.H., M.E. Fey, and H.W. Catts. 2006. Pronominal reference skills of second and fourth grade children with language impairment. Journal of Communication Disorders 39: $232-248$.

Håkansson, G. 2001. Tense morphology and verb-second in Swedish L1 children, L2 children and children with SLI. Bilingualism: Language and Cognition 4: 85-99.

Hansson, K. and L.B. Leonard. 2003. The use and productivity of verb morphology in specific language impairment: An examination of Swedish. Linguistics 41: 351-379.

Johnston, J.R. 2001. An alternate MLU calculation: Magnitude and variability effects. Journal of Speech, Language, and Hearing Research 44: 156-164.

Leonard, L.B., E-K. Salameh, and K. Hansson. 2001. Noun phrase morphology in Swedishspeaking children with SLI. Applied Psycholinguistics 22: 619-639.

Loeb, D.F. and L. Leonard. 1991. Subject case marking and verb morphology in normally developing and specifically language-impaired children. Journal of Speech and Hearing Research 34: 340-346.

Marchman, V.A., C. Saccuman, and B. Wulfeck. 2004. Productive use of the English past tense in children with focal brain injury and specific language impairment. Brain and Language 88: 202-214.

Moore, M.E. 1995. Error analysis of persons by normal and language-impaired children. Journal of Communication Disorders 28: 57-72.

Moore, M.E. 2001. Third person pronoun errors by children with and without language impairment. Journal of Communication Disorders 34: 207-228.

Pretorius, A. 1989. Die Afrikaanse Semantiese Taalevalueringsmedium. Pretoria: Outeur.

Ravid, D., R. Levie, and G.A. Ben-Zvi. 2003. The role of language typology in linguistic development: Implications for the study of language disorders. In Y. Levy and J. Schaeffer (eds). Language competence across populations. Toward a definition of specific language impairment. Mahwah: Lawrence Erlbaum Associates. pp. 171-193.

Ricard, M., P.C. Girouard, and T. Gouin Décarie. 1999. Personal pronouns and perspective taking in toddlers. Journal of Child Language 26: 681-697.

Rispoli, M. 1994. Pronoun case overextensions and paradigm building. Journal of Child Language 21: 157-172.

Rispoli, M. 1998a. Patterns of pronoun case error. Journal of Child Language 25: 533-554.

Rispoli, M. 1998b. Me and my: Two different patterns of pronoun case errors. Journal of Speech, Language, and Hearing Research 41: 385-393. 
Rispoli, M. 2005. When children reach beyond their grasp: Why some children make pronoun case errors and others don't. Journal of Child Language 32: 93-116.

Schütze, C.T. 1999. Different rates of pronoun case error: Comments on Rispoli (1998). Journal of Child Language 26: 749-755.

Southwood, F. 2005. A comparison of the responses to three comprehension and three production tasks assessing the morpho-syntactic abilities of Afrikaans-speaking preschoolers. Per Linguam 21: 36-59.

Southwood, F. 2006. An investigation of the morpho-syntactic abilities of Afrikaans-speaking preschoolers. Southern African Linguistics and Applied Language Studies 24: 33-35.

Southwood, F. and A.F. Russell. 2004. Comparison of conversation, freeplay, and story generation as methods of language sample elicitation. Journal of Speech, Language, and Hearing Research 47: 366-376.

Stark, R.E. and P. Tallal. 1981. Selection of children with specific language deficits. Journal of Speech and Hearing Disorders 46: 114-122.

Vorster, J. 1980. Toets vir mondeling taalproduksie. Pretoria: South-Afrikaanse Instituut vir Psigologiese en Psigometriese Navorsing. 
Bylaag A1: Inligting oor deelnemers met taalgestremdheid se taaltoetsresultate (AST, ARW, TMT)

\begin{tabular}{|c|c|c|c|c|c|c|c|c|c|c|c|}
\hline \multirow[t]{2}{*}{ STG } & \multirow[t]{2}{*}{$\mathbf{K A}^{\mathrm{a}}$} & \multicolumn{8}{|c|}{ AST } & \multirow{2}{*}{$\begin{array}{l}\mathbf{A} \\
\mathbf{R} \\
\mathbf{W}\end{array}$} & \multirow{2}{*}{$\begin{array}{c}\mathbf{T} \\
\mathbf{M} \\
\mathbf{T}\end{array}$} \\
\hline & & 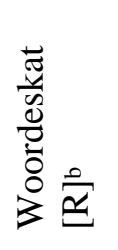 & 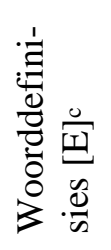 & 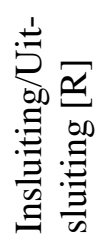 & 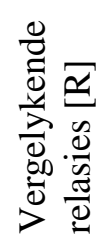 & 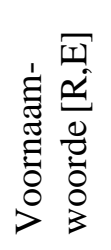 & 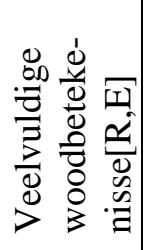 & 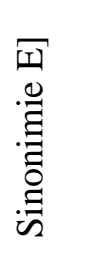 & 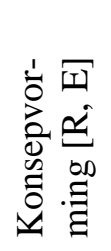 & & \\
\hline 1 & 67 & - & - & - & - & - & - & - & - & $83^{\mathrm{d}}$ & - \\
\hline 2 & 76 & - & - & - & - & - & - & - & - & $<68$ & - \\
\hline 3 & 62 & - & - & - & - & - & - & - & - & - & - \\
\hline 4 & 80 & $60-65$ & - & - & - & - & - & - & - & - & - \\
\hline 5 & 76 & $54-59$ & $48-56$ & - & 60-62 & $36-47$ & $51-71$ & - & - & - & - \\
\hline 6 & 74 & $45-47$ & 69-74 & - & - & - & - & 63-68 & $78-80$ & - & - \\
\hline 7 & 72 & $54-59$ & $<36$ & - & - & - & - & $36-47$ & $48-59$ & - & - \\
\hline 8 & 57 & - & - & - & - & - & - & - & - & - & - \\
\hline 9 & 77 & - & - & - & - & - & - & - & - & - & - \\
\hline 10 & 77 & - & - & - & - & - & - & - & - & - & - \\
\hline
\end{tabular}


Bylaag A2: Inligting oor deelnemers met taalgestremdheid se taaltoetsresultate (middele buiten die AST, ARW, TMT)

\begin{tabular}{|c|c|c|c|c|c|c|c|c|}
\hline \multirow[b]{2}{*}{$\underbrace{}_{-1}$} & \multirow[b]{2}{*}{$\$$} & \multicolumn{4}{|c|}{ TACL-R/III } & \multirow[b]{2}{*}{ Renfrew } & \multirow[b]{2}{*}{ Informele toetsing } & \multirow[b]{2}{*}{ Ander } \\
\hline & & $\begin{array}{l}\frac{n}{\pi} \\
\frac{\pi}{0} \\
0 \\
0 \\
3\end{array}$ & 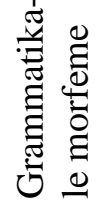 & 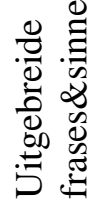 & 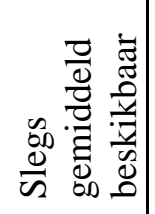 & & & \\
\hline 1 & 67 & -- & -- & -- & & $\begin{array}{l}\text { Ouderdoms- } \\
\text { toepaslike } \\
\text { sinslengte }\end{array}$ & $\begin{array}{l}\text { Wordvolgorde en gebruik } \\
\text { van grammatikale } \\
\text { morfeme afwykend }\end{array}$ & -- \\
\hline 2 & 76 & -- & -- & -- & & -- & $\begin{array}{l}E^{\mathrm{b}} \text { gebruik van meervoude, } \\
\text { voornaamwoorde proble- } \\
\text { maties. } \mathrm{R}^{\mathrm{c}} \text { taal ten minste } 8 \\
\text { maande vertraag; beide } \mathrm{R} \\
\text { en } \mathrm{E} \text { ouderdomsontoepas- } \\
\text { lik. Oorgebruik van om- } \\
\text { skrywings }\end{array}$ & -- \\
\hline 3 & 62 & $\begin{array}{l}51- \\
54\end{array}$ & $\begin{array}{r}41- \\
44\end{array}$ & $\begin{array}{c}53- \\
55\end{array}$ & & -- & -- & -- \\
\hline 4 & 80 & -- & -- & -- & & $\begin{array}{l}39 \text {, } \\
\text { Woordvin- } \\
\text { dingspro- } \\
\text { bleme }\end{array}$ & $\begin{array}{l}\mathrm{E} \quad \text { taal moontlik } \text { op } \\
\text { dieselfde vlak as } \mathrm{R}\end{array}$ & -- \\
\hline 5 & 76 & -- & -- & -- & & -- & -- & $\mathrm{GLU}^{\mathrm{d}}=5.7$ \\
\hline 6 & 74 & -- & -- & -- & -- & -- & - & - \\
\hline 7 & 72 & -- & -- & -- & & -- & -- & -- \\
\hline 8 & 57 & -- & -- & -- & & - & - & $\begin{array}{l}\text { PLS-3 } \\
\text { R 58, E } 48\end{array}$ \\
\hline 9 & 77 & -- & -- & - & & -- & - & $\begin{array}{l}\text { TOLD-P } \\
\text { R 72, E } 54 \\
\end{array}$ \\
\hline 10 & 77 & . & & & 66 & -- & E taal 60 & -- \\
\hline
\end{tabular}




\section{Bylaag B: Toetsitems (nie in aanbiedingsvolgorde nie)}

\section{Items van die prentseleksie- (begrips-)taak}

Oefenitems: $\quad$ Wys vir my 'Hy staan in die hoekie'

Dit is haar skoen

Ek staan langs die tafel

Dit is my roomys

Die voël sit op my

Die kat lek my

Jy staan op die stoel

Dit is jou roomys

Die voël sit op jou

Die kat krap jou

Hy sit by die tafel

Dit is sy roomys

Die voël sit op hom

Die kat lek hom

Sy sit by die tafel

Dit is haar roomys

Die voël sit op haar

Die kat lek haar

\section{Items van die oordeel- (begrips-)taak}

Oefenitem: $\quad$ Ek is wakker

*Dit is sy hoed [i.p.v. my]

Die roomys val op my

*Die hond krap ek [i.p.v. my]

*Jou slaap [i.p.v. jy]

Dit is jou roomys

*Die skoenlapper sit op haar [i.p.v. jou]

Die hond krap jou

*Sy is wakker [i.p.v. hy]

*Dit is hom hoed [i.p.v. sy]
Dit lê op die grond [dit = die koerant]

Sy oor is af [sy= die koppie se]

Die koerant lê daarop [= op die tafel]

Ouma vryf dit [dit = 'n kussing]

Ons wys 'n prentjie

Dit is ons speelgoed

Die reën val op ons

Die seuntjie sien ons

Julle wys 'n prentjie

Dit is julle speelgoed

Die reën val op julle

Die seuntjie sien julle

Hulle wys 'n prentjie

Dit is hulle speelgoed

Die reën val op hulle

Die seuntjie sien hulle
Die eend swem langs hom

Die krap knyp hom

Sy staan

Dit is haar roomys

*Die vark kyk na sy [i.p.v. haar]

*Die hond dra jou [i.p.v. haar]

*Sy staan in die hoek [i.p.v. dit, waar dit = 'n besem]

Sy hare is af hoek [waar sy = 'n besem se] 
Die koppies staan bo dit

*Ouma hou haar vas [i.p.v. dit, waar dit = breiwerk]

Ons lees boeke

*Dit is hulle kar [i.p.v. ons]

*Die hond spring oor julle [i.p.v. ons]

Die koei jaag ons

*Hy lees boeke [i.p.v. julle]
*Dit is haar roomyse [i.p.v. julle]

Die hond spring oor julle

Die koei jaag julle

Hulle lees boeke

*Dit is hulle tuin [i.p.v. julle]

Die hond spring oor hulle

*Die skaap jaag ons [i.p.v. hulle]

\section{Items van die sinsvoltooiings- (produksie-)taak}

Oefenitems: $\quad$ Sy eet 'n roomys, maar (hy eet ' $n$ appel)

Dit is sy koffie en dit is (haar melk)

Hy eet 'n roomys, maar (ek eet 'n appel)

Hy eet waatlemoen, maar (ek eet koek)

Dit is my romp en dit is (my broek/romp)

Dit is my voet en dit is (my neus)

Die eekhoring sit langs my en die hond sit (langs my)

Die voël sit op my en die haas sit (op my)

Dié kat krap my en dié kat krap (my)

Die koei jaag my en die perd jaag (my)

Hy staan, maar (jy sit)

Hy lê, maar (jy staan)

Dit is sy lepel en dit is (jou mes)

Dit is sy oë en dit is (jou hare)

Dié hond sit langs hom, maar dié hond sit (langs jou)

Dié perd spring oor hom, maar dié perd spring (oor jou)

Dié hond krap hom, maar dié hond lek (jou)

Dié hoender pik hom, maar dié hoender pik (jou)

Hy eet pizza, maar (sy eet 'n stokkielekker)

Hy voer die eekhoring, maar (sy voer die voëls)

Dit is my hand en dit is (haar hand)

Dit is sy kar en dit is (haar bal)

Die hond sit langs my en die kat sit (langs haar) 
Dié slang seil oor my en dié slang seil (oor haar)

Die hond lek my en die kat krap (haar)

Dié perd sien my en dié perd sien (haar)

Sy hang in die lug, maar (hy sit op die grond)

Jy staan op die tafel, maar (hy staan op die stoel)

Dit is haar swembroek en dit is (sy trui)

Dit is my glas en dit is (sy glas)

Die baba kyk vir my en die hond kyk (vir hom)

Die hond kyk vir jou en die perd kyk (vir hom)

Die hond lek my en die baba lek (hom)

Dié bul skop haar en dié bul skop (hom)

Ek is skoon, maar (dit is vuil) [waar dit = 'n handdoek]

Jy is groot, maar (dit is klein) [waar dit = 'n klein figuurtjie]

Dit is haar nek en dit is (sy nek) [waar sy = 'n bottel se]

Dit is haar tande maar dit is (sy tande) [= 'n kam se tande]

Die baba kyk vir my en die hond kyk (daarvoor / daarna / vir dit) [= vir 'n klein figuurtjie]

Dié apie spring oor my en dié apie spring (daarin / in dit) [= in 'n boks]

Die hond lek my en die seuntjie lek (dit) [waar dit = 'n klein figuurtjie]

Dié kat krap my en dié kat krap (dit) [waar dit = 'n rusbank]

Sy drink water, maar (ons eet vrugte)

Sy spring tou, maar (ons praat op die foon)

Dit is hulle musse en dit is (ons skoene)

Dit is haar tasse en dit is (ons tasse)

Die voël vlieg oor hulle en die vlieër vlieg (oor ons)

Die vliegtuig vlieg oor hom en die helikopter vlieg (oor ons)

Die kat krap hom en die honde lek (ons)

Dié vark sien hom en dié vark sien (ons)

Ons eet koek, maar (hulle eet roomys)

Ons staan, maar (hulle sit)

Dit is ons hare en dit is (hulle hare)

Dit is sy boek en dit is (hulle boeke)

Die voël sit op my en die voëls sit (op hulle)

Dié emmer val op my en dié emmer val (op hulle) 
166 Frenette Southwood

Die hond lek haar en die katte krap (hulle)

Dié seun stamp haar en dié seun stamp (hulle)

Sy eet appels, maar (julle eet piesangs)

Hy sien 'n skaap, maar (julle sien 'n koei)

Dit is haar bene en dit is (julle bene)

Dit is sy hond en dit is (julle honde)

Die skoenlapper sit op jou en die skoenlappers sit (op julle)

Dié bal hop op jou en dié bal hop (op julle)

Die vark lek hom en die honde lek (julle)

Dié seun spuit hom nat en dié seun spuit (julle) nat 